KYIV-MOHYLA

HuMANITIES JOURNAL

KYIV-MOHYLA SCHOLARLY PEER-REVIEWED JOURNALS

Ideological Zealots Fighting a Non-Existent Ukrainian Nationalist Enemy: A Reply to Tarik Amar's Review of Red Famine

Author(s): Taras Kuzio

Source: Kyiv-Mohyla Humanities Journal 6 (2019): 209-216

Published by: National University of Kyiv-Mohyla Academy

http://kmhj.ukma.edu.ua/ 


\title{
Ideological Zealots Fighting a Non-Existent Ukrainian Nationalist Enemy: A Reply to Tarik Amar's Review of Red Famine
}

\author{
Taras Kuzio
}

National University of Kyiv-Mohyla Academy, Department of Political Science

Tarik Cyril Amar's review “Politics, Starvation, and Memory” of Anne Applebaum's Red Famine. Stalin's War on Ukraine, a book about the Holodomor, was published in Kritika: Explorations in Russian and Eurasian History (vol. 20, no. 1, 2019). Applebaum's Red Famine was published in Ukrainian by the Institute of History, National Academy of Sciences as Chervonyi holod. Viina Stalina proty Ukrainy. In December 2018, the National University of Kyiv-Mohyla Academy awarded Applebaum an honorary doctorate at an evening to honor her long record of writing about Ukraine and her then new book Red Famine.

In my own review of Red Famine published in the academic journal Europe-Asia Studies (vol. 70, no. 8, October 2018) I described Applebaum as a "contemporary Robert Conquest." In 1986 Conquest, the well-known historian of the USSR, published the groundbreaking Harvest of Sorrow about the Holodomor at a time when research was reviving about Joseph Stalin's crime against Ukraine just after its 5 oth anniversary and also on the eve of revelations that became public during Soviet leader Mikhail Gorbachev's glasnost. The Holodomor was denied by the Soviet regime until 1990 and Conquest had to work with no access to Soviet archives but nevertheless, he provided a history of this Stalinist crime that the academic world could no longer ignore. In contrast, Applebaum was able to access archives because the 2015 de-communization laws gave Ukraine the most liberal access to USSR archives of any former Soviet state outside the three Baltic republics. Amar was one of the Western academics who condemned the de-communization laws in an open letter published in Krytyka. ${ }^{1}$

Amar's review is unusually long and surprisingly, it discusses the topic of her book on only 5 of its 24 pages. Although Amar was given 24 pages to review a book the editors of Kritika only provided 2 pages to respond, which would be insufficient to provide a full discussion of his ideologically driven discussion.

Amar used his review of Red Famine to continue an ideological campaign by him and a number of his other colleagues where they discuss all aspects of Ukrainian history through the alleged "evils of Ukrainian nationalism." Applebaum's Red Famine is clearly a book about the Holodomor of 1933 and not about Ukrainian nationalist groups in the 1940 s or Ukrainian nationalist émigrés in the Cold War.

$1 \quad$ David R. Marples, "Open Letter from Scholars and Experts on Ukraine Re. the So-Called 'Anti-

Communist Law,"” April 2015, accessed May 18, 2018, https://krytyka.com/en/articles/open-

letter-scholars-and-experts-ukraine-re-so-called-anti-communist-law. 
When reading various passages in the review one is therefore simply bewildered by why Amar feels such a strong need to engage in battle with a non-existent opponent, such as when he writes that "...Red Famine also fails to deal with World War II" (p.150). This is as nonsensical as would be a reviewer writing that my 2017 book Putin's War Against Ukraine. Revolution, Nationalism and Crime (published in Ukrainian and Russian by Dukh i Litera in $2019^{2}$ ) fails to deal with the 2004 Orange Revolution.

Amar's overarching interest and concern appears to be the question of collaboration by Ukrainian nationalists with the Germans during World War II, and everything else-including the 1932-1933 famine (the Holodomor) (that is the subject of the book he is reviewing!), Polish-Ukrainian relations, the Ukrainian diaspora, the Cold War, Russia's military aggression against Ukraine, de-communization and other topics becomes secondary or tertiary. His review does not, therefore, read as a discussion of Applebaum's study of the Holodomor but, instead, as an essay that assembles various examples of the avowedly perfidious nature of "Ukrainian nationalists" during World War II, the Cold War, and since the Euromaidan Revolution.

Why? What is the relevance of this subject to Applebaum's book? And, why did Kritika think it was relevant enough to publish such a strange review?

At an early point in the review, Amar criticizes Applebaum for her "selective" use of sources (p. 148), which is both untrue and an example of the author's own double standards. Amar's essay is dominated by references to his own work and the work of his fellow ideological zealots (e. g., Per Anders Rudling, Grzegorz RossolinskiLiebe, and John-Paul Himka) while on no occasion does he cite any of the prominent North American scholars with major publications on Ukrainian history, such as Serhii Plokhy, Paul R. Magosci, Orest Subtelny, Myroslav Shkandrij, or George Liber. His highly selective use of sources ignores scholarly works on the Holodomor by non-diaspora scholars, such as Timothy Snyder, Norman Naimark, Andrea Graziosi and others. There are also barely any scholars or works from Ukraine included in his references. Rudling, Rossolinski-Liebe, and Himka, the authors Amar does cite, are not internationally recognized scholars on the Holodomor and have instead focused their scholarly work on the 1940s and Ukrainian nationalism, although Himka has written about a broader range of subjects.

Amar touches upon but never explores any of the key issues that Applebaum and more recent writers have tried to address and that are central to any discussion of the Holodomor. It is at this point in time indisputable that the Soviet leadership targeted Ukraine and the Ukrainian population (here understood as not just ethnic Ukrainians but all the people living in Ukraine). There is not, however, consensus about whether Ukraine's famine fits the definition of a genocide. Nonetheless, it is unclear why if there were Soviet famines elsewhere in the USSR this should challenge Applebaum's depiction of the Holodomor as directed against Ukraine and Ukrainians, which Amar seems to be suggesting. And, while discussing Soviet policies towards Kazakhstan and 
other Soviet regions, Amar surprisingly does not cite or address Snyder's 2010 book Bloodlands. Europe Between Hitler and Stalin, which differentiates between famine in Ukraine that he describes as a genocide, and famine in Kazakhstan, which he does not. The Kazakhs opposed Soviet policies of collectivization, but Kazakh nationalists were not viewed as a threat to the territorial integrity of the USSR, and Stalin did not have an obsession with the Kazakhs as he clearly did with Ukrainians (and Poles, but that is a different story).

Amar's does not agree with the view that the Soviet leadership targeted Ukraine and the population in Ukraine and believes this has its origins within mythology thought up by the Ukrainian nationalist diaspora. Amar holds the same view as that of pro-Russian former President Viktor Yanukovych and Russia that the famine affected the entire USSR and was not aimed against Ukraine. Amar does not discuss the fact that $79 \%$ of Ukrainians believe the Holodomor was a "genocide." ${ }^{3}$

Amar's pivot away from his comparatively brief discussion of the Holodomor is introduced in a paragraph of his essay that is deceptively inconspicuous:

Yet, on the whole, for Applebaum inscribing the Ukrainian famine into what emerges in her book as a terrible but also triumphant story of the perseverance and rise of the Ukrainian nation clearly overrides evidence disturbing this narrative. Partly, this appears to be due to Red Famine's lack of critical distance toward a long émigré tradition that Applebaum is free to admire and celebrate, as she does. But she should not fail to query it in earnest as well, a failure that seems to be due to her-laudably explicit - sympathy for Ukrainians opposing the Soviets. Indeed, her quotation from a 1959s émigré publication describing the famine as "Red Moscow[']s ... most ignominious plan to break the power of resistance of ... the Ukrainian nation" could serve as a capsule synopsis of Red Famine (pp. 148-149).

After reading the entire Amar review, it becomes clear that this paragraph conceals not one but several implicit non sequiturs, all having to do with the concept of relevance. To begin, the Holodomor took place in 1932-1933. World War II took place in 1939-1945, six years later. For purposes of unpacking what did or did not happen in 1932-1933, whatever some Ukrainian nationalists may or may not have done during WWII is not relevant. Similarly, for purposes of unpacking the famine in Ukraine in 1932-1933, it is irrelevant what the Ukrainian diaspora may or may not have said or done after WWII.

Leaving aside the key issue of the relevance of events that chronologically succeeded Red Famine's subject and addressing Amar's discussion of Ukrainian 
nationalism on his terms, it appears that his zealous preoccupation with "the evils of Ukrainian nationalism" prevents him from understanding this subject in any kind of a comparative context. Thus, for example, all of the five characteristics that he defines as negative aspects of Ukrainian nationalism were applicable to most of the countries in Europe in the 1930s and 1940s. The Netherlands, for example, had far more people who were collaborators in World War II (including providing manpower for two Waffen SS Divisions) than joined its tiny anti-Nazi underground.

A common problem of some historical discussions of western Ukraine during World War II is that such discussions choose to focus solely on atrocities committed by Ukrainian nationalists and misrepresent, by omission or commission, what Ukrainian historians have actually written about WWII. Thus, in his review Amar pointedly refuses to acknowledge that most Ukrainian historians, including Volodymyr Viatrovych, the director of Ukraine's Institute of National Memory, ${ }^{4}$ whom he cites, write that Ukrainian nationalists undertook atrocities and even that in certain areas they killed more than their opponents. But what Ukrainian historians have explained, and what Amar neglects to include in his review essay, is that the Polish side also committed atrocities against Ukrainian civilians in the 1940s. A balanced condemnation of civilian atrocities should therefore include those committed by the AK (Home Army), BCh (Peasant Battalions), NSZ (National Armed Forces) and Polish Communist forces as well as those committed by the OUN (Organisation of Ukrainian Nationalists) and the UPA (Ukrainian Insurgent Army). An interesting question that this fact prompts is, would Poland agree to no longer honor $\mathrm{AK}, \mathrm{BCh}$, and NSZ - the same demand Warsaw (and Amar and his zealous colleagues and the open letter in Kryty $k a^{5}$ ) are making of Ukraine to not honor OUN and UPA? We could take this argument further and demand that the monument to Oliver Cromwell be removed from the British parliament as his forces committed genocide in Ireland where they murdered $40 \%$ of the Catholic population. Or demand that France stop honoring Napoleon, whose military campaigns led to the deaths of millions of Europeans.

When Western scholars do not demand equal condemnation of both sides for the commission of similar atrocities, they are helping to support Poland's victimisation complex ${ }^{6}$ that is promoted to a much greater extent by the ruling Law and Justice Party than anything that was ever undertaken in Ukraine by former President Petro Poroshenko.

Another omission in Amar's narrative is produced by his over-concentration on pogroms in 1941. This leads him to ignore that OUN leaders were imprisoned from

Taras Kuzio, "Umland Needs a More Balanced Approach," New Eastern Europe, April 11, 2017, accessed May 24, 2018, http://neweasterneurope.eu/2017/04/11/umland-needs-a-morebalanced-approach/.

$5 \quad$ Marples, "Open Letter from Scholars and Experts."

6 Taras Kuzio, “The Genocide Myth and Poland's Victimisation Complex,” New Eastern Europe, December 1, 2017, accessed March 1, 2019, http://neweasterneurope.eu/2017/12/o1/genocidemyth-polands-victimisation-complex/. 
summer 1941 onwards by the Nazis, Stepan Bandera's two brothers were murdered in Auschwitz, and the Nazis arrested, tortured and executed tens of thousands of Ukrainian nationalists. All of this amounts to a rather unusual form of "collaboration." And it is interesting to note that whereas OUN and AK launched their respective anti-Nazi resistance at approximately the same time in early 1942, Ukrainian policemen deserted the Nazis in March 1943 nearly a year before Polish policemen defected from the Nazis. When do Amar and his colleagues ever discuss Polish policemen collaborating with the Nazis?

Amar writes that Applebaum's Red Famine is "badly stuck in the past, tied to the cultural Cold War as if it had never ended" (p. 162). With the Cold War as his backdrop, Amar discusses the Ukrainian diaspora as some monolithic nationalist group in a similar way to how he adopts a blanket approach to the promotion of patriotism in post-Euromaidan Ukraine. Strangely, both approaches lead down a path that is surprisingly close to what Soviet propaganda used to write about the Ukrainian diaspora and what contemporary Russian information warfare disseminates about Ukraine and Ukrainians. A "bourgeois nationalist" in the USSR could be anybody who criticized the Soviet system, ranging from a national communist, liberal dissident to a nationalist. Contemporary Russia's understanding of a "fascist" is any Ukrainian who does not desire that Ukraine be a part of Vladimir Putin's Russian World. Yet what seems to alarm Amar is that, according to him, Applebaum failed "to take seriously the pertinence of the legacies of Ukrainian and Cold War nationalism” (p. 169).

Amar, as do some other Western scholars such as David Marples who together with James Sherr wrote the open letter published in Krytyka, is critical of policies and the writing of scholars that place Communist and Nazi totalitarianism on the same criminal level. Marples is not only opposed to moral equivalence of Nazi and Communist totalitarianism but he is strongly opposed to de-communization in general. ${ }^{7}$ This equivalence has been enshrined in six resolutions adopted by European and international organizations between 2006-2009. ${ }^{8}$ And Amar, as does Marples, does not accept the negative equalization of the two totalitarian systems. This appears to be

7 David Marples, "Decommunization, Memory Laws, and 'Builders of Ukraine in the 2oth Century," Acta Slavica Iaponica 39 (2018): 1-22, accessed May 2, 2019, http://src-h. slav. hokudai.c.jp/publictn/acta/39/pp.\%201\%E 2\%80\%9322.pdf.

8 Parliamentary Assembly of the Council of Europe (PACE) resolution "strongly condemns crimes of totalitarian communist regimes" (January 2006), (EU) European Public Hearing on Crimes Committed by Totalitarian Regimes (April 2007), Prague Declaration on European Conscience and Communism (June 2008), European Day of Remembrance for Victims of Stalinism and Nazism ('Black Ribbon Day') commemorated by EU institutions on 23 August (September 2008), European Parliament resolution on European conscience and totalitarianism condemned totalitarian crimes and called for the recognition of "Communism, Nazism and fascism as a shared legacy" (April 2009), and Vilnius Declaration of the Organisation for Security and Cooperation in Europe (OSCE) condemned Soviet and Nazi totalitarianism (June/July 2009). 
the source of their seeming visceral opposition to Ukraine's four de-communization laws. The irony is that the majority of the signatories of the April 2015 open letter had never read the laws which were only published in the Ukrainian media a month later; indeed, some scholars such as Serhiy Zhuk have stated they regretted signing it because they have gone on to use the archives opened by the laws.

Russia's information warfare since 2014 has heavily targeted Ukraine to such an extent that today Russians view Ukraine as negatively as they view the US. The European Union's Disinformation Review describes Russia's information warfare against Ukraine as "Belittle, Ridicule, and Dehumanise." "The combination of disinformation and denigrating language serves as an example of how Russia uses communication as a hybrid form of aggression, which it in this case integrates into a military confrontation with a foreign country." 9 The most persistent message on Russian TV and information warfare is that Ukrainians (often described using the derogatory khokhli) are not a nation and purportedly that Ukraine is a "failed" and "artificial" state.

"Almost five years into the conflict between Russia and Ukraine, the Kremlin's use of the information weapon against Ukraine has not decreased; Ukraine still stands out as the most misrepresented country in pro-Kremlin media," the European Union's Disinformation Review concluded. Ukraine by far tops the European Union's Disinformation Base "as the most frequent target with 461 references among a total of 1,00o disinformation cases reported in the course of 2018."

However unintentionally, Amar contributes to such Russian disinformation because his critical discussion of Ukraine's de-communization laws is entirely devoted to a single aspect of but one of the four laws, thereby providing an unbalanced analysis of them. This seems to be undertaken in order to claim that, allegedly, it is "state policy in Ukraine" to promote Bandera. But it is a gross exaggeration to claim that President Poroshenko made some supposed cult of Bandera into a Ukrainian "state-imposed glorification of Ukrainian World War II nationalists" (p. 163). The 40-person staff of the Ukrainian Institute of National Memory represents only $4 \%$ of the number of employees at its Polish equivalent. And, the de-communization laws do not honor Ukrainian units who served in German forces, which makes it difficult to understand how or why, as Amar claims, these laws lead to the supposed cult of the Galicia Waffen SS Division.

Amar's depiction of de-communization leading to a "wave of honoring World War II nationalists with monuments, plaques, and street names" (p. 164) has little basis in reality. In most cases, monuments to Vladimir Lenin have not been replaced by those dedicated to Bandera. In the majority of instances in which place names have been changed, such names have reverted from Soviet Communist names to old local names or to entirely new ones, such as when Dnipropetrovsk became Dnipro.

In his discussion of Polish-Ukrainian interactions, Poland's widespread veneration of Polish nationalist partisan groups in World War II, who as pointed out earlier were guilty of committing atrocities against Ukrainian civilians in the 1940s, appears to be 
of no interest to Amar or his equally zealous colleagues who have also written on this subject. And it is noteworthy that President Poroshenko never instructed employees in his presidential administration to read Bandera or the writings of any other nationalist leaders. Yet Russian President Putin did instruct regional governors and leaders of the United Russia party to read works by the white émigré Ivan Ilyin, whose remains were ceremoniously returned to Russia as early as 2005 for reburial. Ilyin was not only a fascist and anti-Semite, but he was also typical of Russian nationalists in denying the existence of the Ukrainian nation. ${ }^{10}$ No Ukrainian nationalist (including Bandera!), Amar's bete noire, has ever denied the existence of the Russian or Polish nations.

Amar's depiction of Ukraine as being supposedly run by nationalists is also to be found in some Western writing on the conflict in the Donbas, which $72 \%$ of Ukrainians believe is a war between Ukraine and Russia. ${ }^{11}$ This genre of Western writing by scholars is often deferential to Putin and Russia. ${ }^{12}$ Amar, in ways similar to these pro-Russian authors, defines 'nationalist' in a way that has nothing to do with political science but all to do with traditional Soviet and contemporary Russian messaging about "nationalists" that groups together anti-Soviet dissidents and nationalists in the USSR together with contemporary Ukrainians who support European integration and who wish to create distance between themselves and the so-called Russian World. Ironically, when defined in terms of their electoral influence, Ukraine has one of the lowest levels of support in Europe for nationalist political parties. In the 2014 elections, Ukrainian nationalist parties failed to enter parliament, and in the 2019 elections the nationalist presidential candidate came in 9 th with less than $2 \%$ of the vote. Presumably Amar thinks, like in Russia, that all pro-Western politicians in Ukraine (including presumably Volodymyr Zelenskyi) are "nationalists" running the only country outside Israel with a Jewish president and Jewish prime minister.

Amar attempts to portray Presidents Yushchenko and Poroshenko as being different from Ukraine's other presidents by claiming that their periods in office were supposedly dominated by state policies promoting "nationalism." So according to Amar, Yushchenko was the first Ukrainian president "to initiate an aggressively nationalist

10 Anton Barbashin and Hannah Thoburn, "Putin's Philosopher: Ivan Ilyin and the Ideology of Moscow's Rule," Foreign Affairs, September 20, 2015, accessed April 2, 2019, https://www. oreignaffairs.com/articles/russian-federation/2015-09-20/putins-philosopher.

"Poshuky shliakhiv vidnovlennia suverenitetu Ukrainy nad okupovanym Donbasom: stan hromadskoi dumky naperedodni prezydentskikh vyboriv [Search for Paths to Renew Ukrainian Sovereignty Over Occupied Donbas: Public Opinion on the Eve of the Presidential Elections]," Fond Demokratychni Initsiatyry imeni Ilka Kucheriva, February 13, 2019, accessed May 24, 2019, https://dif.org.ua/article/poshuki-shlyakhiv-vidnovlennya-suverenitetu-ukraini-nadokupovanim-donbasom-stan-gromadskoi-dumki-naperedodni-prezidentskikh-viboriv.

12 See my reviews of Western writing on the Ukrainian-Russian war in "Russia-Ukraine Crisis: The Blame Game, Geopolitics and National Identity," Europe-Asia Studies 70.3 (2018): 462-73 and "Euromaidan Revolution, Crimea and Russia-Ukraine War: Why it is Time for a Review of Ukrainian-Russian Studies," Eurasian Geography and Economics 59.3-4 (2018): 529-53. 
memory politics - again, while also making the famine a priority" (p. 164). This is a misrepresentation of the facts. During President Leonid Kuchma's two terms in office (1994-2004), Ukrainian historiography and the textbooks prepared for use in Ukraine's schools had already incorporated narratives about the OUN and the UPA, as well as about Ukrainians who had fought in other non-Soviet forces, into the teaching and writing about history. Yushchenko merely integrated this new writing of history into his presidential decrees.

Similarly, as regards the Holodomor, it was during Kuchma's presidency that it was defined as a genocide. In fact - and ironically, given his subsequent conduct during the Yanukovych period - in 2003 on the 7oth anniversary of the Holodomor, Deputy Prime Minister Dmytro Tabachnyk toured the world lobbying governments to support the Holodomor as a genocide. Yushchenko and Poroshenko continued where Kuchma had left off. The actual exception to the policies of Ukraine's presidents was rather Yanukovych, who adopted Russia's demands for "corrections" to Ukrainian views of the famine as articulated in Russian President Dmitri Medvedev's August 2009 open letter to President Yushchenko. Amar ignores the roots of Ukraine's memory politics in Kuchma's presidency because it does not fit his patently wrong framework of a "nationalist Ukraine."

It is really perplexing why Amar and Kritika chose to miss an opportunity to launch a discussion of the contemporary state of scholarship on the Holodomor, which opportunity was afforded by the publication of Applebaum's Red Famine. Instead, Amar's long review of Applebaum's Red Famine was used as a stage for an altogether different objective, that of continuing his ideological crusade against real and imagined "Ukrainian nationalists" in the 1940s and Cold War, Ukrainian émigrés, Yushchenko, Poroshenko, and de-communization.

Taras Kuzio is a Professor in the Department of Political Science, National University of Kyiv Mohyla Academy and a Non-Resident Fellow, Foreign Policy Institute, School of Advanced International Studies, Johns Hopkins University. He is the author and editor of seventeen books, five think tank monographs, and author of 38 book chapters and 100 scholarly articles on post-communist and Ukrainian politics, democratic transitions, nationalism and national identity, and European studies. 